\title{
Tularemia: A Rare Cause of Neck Mass
}

\author{
Original Investigation Turgut Karlıdağ $\breve{~}^{1}$, Erol Keleş ${ }^{1}$ İrfan Kaygusuz ${ }^{1}$, Koray Yüksel $^{2}$, Şinasi Yalçın ${ }^{1}$ \\ ${ }^{1}$ Department of Otorhinolaryngology, Firat University Faculty of Medicine, Elazığ, Turkey \\ ${ }^{2}$ Department of Otorhinolaryngology, Bingöl State Hospital, Bingöl, Turkey
}

Abstract Objective: Tularemia is a bacterial zoonosis caused by Francisella tularensis. In this study, we aimed to retrospectively evaluate the documents of patients who had a diagnosis of tularemia in our hospital and discuss this condition with a literature review.

Methods: Twenty-five patients who had a diagnosis of tularemia between 2010 and 2013 were included in the study. The patients were assessed with respect to their demographic data; presenting complaints; leukocyte, sedimentation, and $\mathrm{C}$-reactive protein $(\mathrm{CRP})$ values; applied treatment protocols; duration of stay in the hospital; and histopathological examinations.

Results: Fifty-seven patients were admitted to the health department of our clinic with a preliminary diagnosis of tularemia, and the diagnosis of tularemia was serologically confirmed for 25 patients. Pharyngeal mucosa cultures, centrifuged serum samples, and abscess and/or pathological samples were collected from all the patients. Thirteen patients were female, and 12 were

\section{Introduction}

Tularemia disease is a bacterial zoonosis, and it is caused by the bacterium Francisella tularensis, an aerobic, non-encapsulated, and gram-negative coccobacilli (1). Tularemia is known by different names such as “Francis disease, Ohara's disease, rabbit fever, deer-fly fever, Siberian ulcer, and meat-cutter's disease." It has been in the list of notifiable diseases since 2005 (2).

This study was presented as poster at the $35^{\text {th }}$ Turkish National Congress of Otorhinolaryngology and Head and Neck Surgery Conference, Antalya, Turkey. Address for Correspondence:

Koray Yüksel, Bingöl Devlet Hastanesi, Kulak Burun ve Boğaz Hastalıkları Kliniği, Bingöl, Turkey Phone: +90 5053449556 E-mail: korayuksel@hotmail.com Received Date: 27.02.2015 Accepted Date: 28.03.2015

(c) Copyright 2015 by Official Journal of the Turkish Society of Otorhinolaryngology and Head and Neck Surgery Available online at www.turkarchotorhinolaryngol.org (c) Telif Hakkı 2015 Türk Kulak Burun Boğaz ve Baş Boyun Cerrahisi Derneği Makale metnine www.turkarchotorhinolaryngol.org web sayfasından ulaşılabilir. DOl:10.5152/ta0.2015.985 male. The ages of the patients were between 10 and 75 (average $33.12 \pm 15.53$ ) years. The most frequent (100\%) symptom among the patients was swelling in the neck. While abscess drainage was performed in 12 patients (48\%), the neck mass was excised in 3 patients $(12 \%)$, and 10 patients $(40 \%)$ were given only medical treatment. According to the guide of tularemia management by the Ministry of Health, treatment using suitable doses of streptomycin was started for all the patients; in addition, for $8(32 \%)$ patients, doxycycline treatment was added.

Conclusion: In recent years, tularemia in our country has been increasing at some specific locations, and those patients are frequently admitted to polyclinics with a complaint of swelling in the neck. In endemic areas in particular, tularemia should also be considered in the differential diagnosis of patients who present with abscess in the neck.

Keywords: Tularemia, Francisella tularensis, neck abscess

son was detected, and it is more frequently seen among men than among women. The main modes of transmission are arthropod bites, inhalation of infective aerosol, contact with an infected animal, and consumption of tissue or fluid of the infectious animal and contaminated water or food. Hare, squirrel, bird, sheep, beaver, and domestic cats and dogs can be a reservoir (1). Entry route of the agent is generally through skin and mucous membranes. After the agent is inoculated into the skin, its number increases locally in 2-5 days, and it causes an erythematous, stretched, swollen, and itchy papule. With rapid growth of this papule, an ulcer with dark-colored base occurs and then it leads to lymphadenopathy in the adjacent regions. After the development of bacteremia, it can also spread to distant regions. Tularemia includes ulceroglandular, oropharyngeal, glandular, pneumonic, ocular, and typhoidal types. The most common type is oropharyngeal tularemia $(4,5)$.

In this study, the aim was to draw attention to tu- 
laremia disease by evaluating clinical diagnosis, and the treatment of patients diagnosed with tularemia in our department in the light of literature.

\section{Methods}

The study included 25 patients with the diagnosis of tularemia who applied with the complaint of neck abscess to our clinic between January 2010 and December 2013. Before the study, ethics committee approval was received from the Firat University Clinical Research Ethics Committee. The patients were the ones who directly applied to the otorhinolaryngology outpatient clinic or those who were referred to our clinic by other departments for neck swelling. The final diagnosis of tularemia was established by sending tissue sample, throat swab, centrifuged blood sample, and abscess material to the Refik Saydam Hygiene Institute by the Directorate of Health and by evaluating the result of the micro-agglutination test. The patients who were reported to be tularemia positive $(<1 / 160$ titer $)$ in the result from the online queries of the institute were included in the study.

\section{Statistical analysis}

The patients were evaluated with regard to their demographic data, complaints at admission, the values of leucocyte, sedimentation, and $\mathrm{C}$-reactive protein (CRP), implemented treatment protocols, duration of hospitalization, histopathological examination result. While assessing the data obtained, Statistical Package for the Social Sciences ver. 10.0 (SPSS; SPSS Inc., Chicago, Illinois, USA) software was used for statistical analysis.

\section{Results}

A total of 57 patients with the pre-diagnosis of tularemia was reported to the Directorate of Health by our clinic between January 2010 and December 2013. Among these patients, the total number of patients with the final diagnosis of tularemia was 25 ( 13 females and 12 males). The ages of tularemia patients included in the study varied between 10 and 75 years (mean, $33.12 \pm 15.53$ years) (Table 1 ).

All except three patients (12\%) were referred to our hospital from neighboring provinces [10 from Bingöl (40\%), 8 from Muş (32\%), and 4 from Tunceli (16\%)]. Six of those patients (24\%) had a history of the presence of ill individuals with similar complaints around them, and the reasons for applying to hospital were neck swelling (100\%), sore throat, fever, fatigue, and running wound in the neck (Table 2; Figure 1). For the patients at the time of admission, the mean values for leucocyte, sedimentation, and CRP were $9.68 \pm 2.74(3.8-10.3) \mathrm{K} / \mathrm{uL}, 43.69 \pm 17.49$ $(0-20) \mathrm{mm} / \mathrm{h}$, and $12.59 \pm 18.76(0-1) \mathrm{mg} / \mathrm{dL}$, respectively.

Of the patients, 92\% (23/25) were initiated with antibiotic treatment in an external health center before applying to our clinic. All patients underwent neck ultrasonography for differ- ential diagnosis, and when needed, they also underwent magnetic resonance imaging (MRI) of the neck (Figure 2).

Twelve (48\%) of the patients underwent abscess drainage under local anesthesia, three (12\%) patients underwent mass excision operation under general anesthesia, and $10(40 \%)$ patients received only medical treatment. The diagnoses of patients having undergone mass excision under general anesthesia were established with postoperative evaluation of tissue samples for tularemia. One patient re-applied with neck swelling in the third month after abscess drainage, and the patient was administered streptomycin and doxycycline therapy with aspiration. The mean duration of hospitalization was $5.47 \pm 1.77$ days. Samples taken from 19 patients (76\%) were sent for pathological examination; 13 patients (52\%) were reported with cytological findings consistent with abscess content and six (24\%) were reported as having granulomatous inflammatory reaction. In the examination of abscess material, 25 patients (100\%)

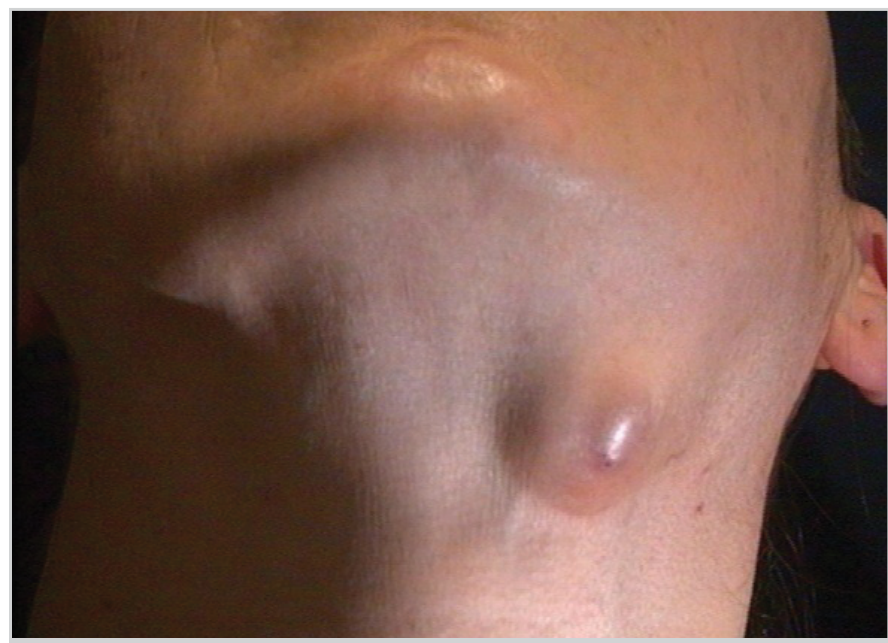

Figure 1. A female patient presenting with the complaint of neck swelling and diagnosed with tularemia

Table 1. Age and gender distributions of patients

\begin{tabular}{l|c|c|c}
\hline Age range & Male & Female & Total (\%) \\
\hline $0-15$ & 1 & 1 & $2(8)$ \\
$16-40$ & 9 & 7 & $16(64)$ \\
$>40$ & 2 & 5 & $7(28)$
\end{tabular}

Table 2. The symptoms of patients at admission

\begin{tabular}{l|c} 
Symptom at admission & Number of patients (\%) \\
\hline Neck swelling & $25(100)$ \\
Sore throat & $16(64)$ \\
Fever & $13(52)$ \\
Fatigue & $12(48)$ \\
Running wound in the neck & $3(12)$
\end{tabular}




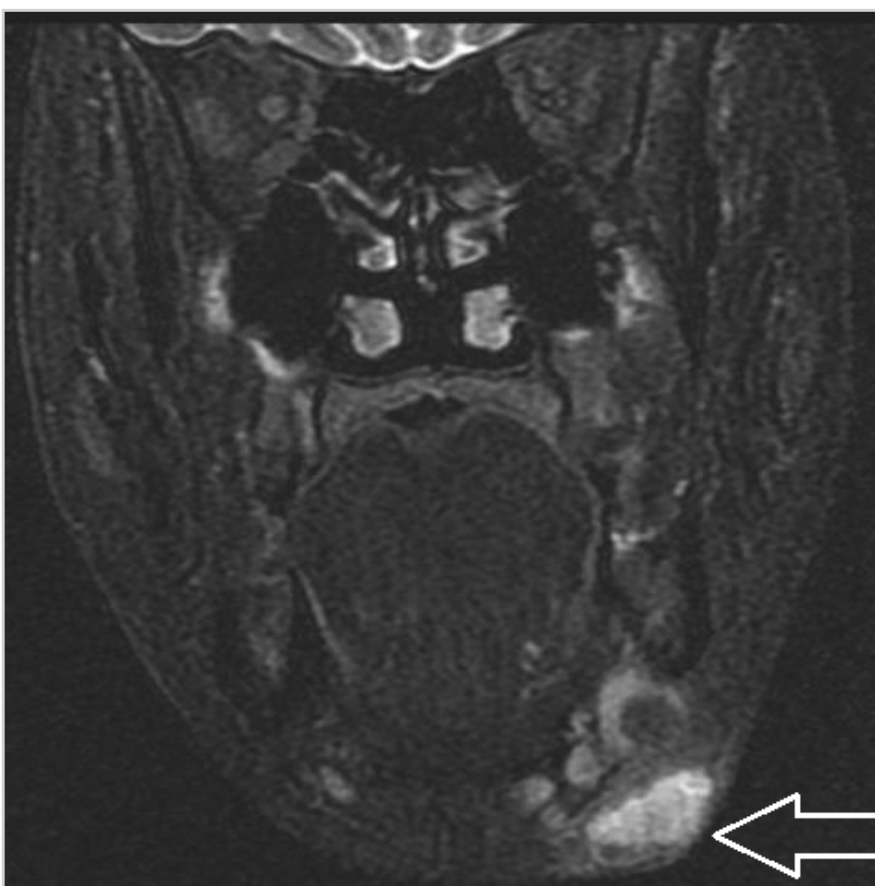

Figure 2. MR image of the patient who was diagnosed with tularemia after examinations

were reported as ARB negative. All patients were initiated with streptomycin therapy at appropriate doses for 10 days in accordance with the field guideline of the Ministry of Health for tularemia. Moreover, doxycycline therapy was additionally administered to eight patients (32\%).

\section{Discussion}

The onset symptoms of tularemia often imitate those of cold. Sudden onset of fever with chills and shivering, myalgia, arthralgia, malaise, anorexia, weight loss, and headache are the symptoms that are frequently seen (5-7). Systemic findings can only include the presence of fever without pneumonia, typhoidal tularemia, and a localized sign (1). Most of the patients (92\%) had been treated in external health centers in the acute phase, and they applied to our clinic because their complaints did not regress and neck swelling occurred additionally. Thereby, neck swelling occupies the first place in the list of symptom frequencies. The progression of patient depends on the virulence of organism, the size of inoculated area, entry site, and the immune state of patient. Neck swelling can be bilateral $(8,9)$.

In a study conducted in the United States of America, it was found that the cause of disease was skin-mediated inoculation at the rate of $75 \%-85 \%$. The disease generally leads to inguinal and femoral lymphadenopathy in adults and cervical lymphadenopathy in children (1). Almost all of the patients in our study were adults, and all patients had cervical lymphadenopathy.

The diagnosis of tularemia is mostly established with agglutination tests (10). The methods used are tube agglutination and micro-agglutination tests. In the standard tube agglutination test, the positivity in $>1: 160$ titer is sufficient for diagnosis. The isolation of F. tularensis with culture is difficult. The organism was isolated in $10 \%$ of 1000 human cases, $84 \%$ of whom were serologically positive (1). A total of 57 patients with the pre-diagnosis of tularemia were reported to the Directorate of Health by our clinic, and tularemia was detected in 25 of them. This lower rate may have resulted from the fact that $92 \%$ of the patients used antibiotics at the time of admission. The agent can be isolated from infected ulcer, lymph node biopsy, gastric lavage, sputum and blood cultures. Today, diagnosis can also be established through the polymerase chain reaction (PCR) technique $(4,8,11)$.

All beta-lactam antibiotics and new-generation cephalosporins are ineffective in tularemia treatment. Quinolones can be used because of the intracellular activity of the agent. At present, the main treatment comprises aminoglycosides (2). The intramuscular administration of $2-\mathrm{g} /$ day streptomycin divided into two doses is efficient in adults. This dose is $15 \mathrm{mg} / \mathrm{kg} /$ day for children. The duration of treatment is 10 days for children and adults (2). In approximately a quarter of the patients who have slow clinical improvement, treatment can last for more than 2 weeks (12). In our series, adult patients were given 1-g streptomycin twice a day, and the pediatric patients were given 15-mg/ $\mathrm{kg} /$ day streptomycin divided into two doses. No recurrence was observed, except in one case. The patient who had recurrent tularemia underwent drainage with injection again and quinolone was added to the treatment.

After an efficient treatment, the fever is reduced in two days, and skin lesions and lymph nodes can heal in about 2-4 weeks (8). The lymph nodes in the neck are in the shape of reactive lymph node not including necrosis and pus at the beginning of the disease, particularly in the first week. After the second week, abscess can develop in the lymph nodes. If this time exceeds 4 weeks, caseous necrosis can also occur (13). It was reported that almost half of the patients had suppurative inflammation, and only $8 \%$ had caseous necrosis. This situation can be interpreted as tuberculosis lymphadenitis in patients having caseification, and it can result in wrong approaches with regard to treatment $(12,14)$.

Most of the cervical lymphadenitis associated with tularemia are exposed to resolution with effective medical treatment. The formation of abscess can occur in some patients, and the initial aspiration of abscess content with injection can be adequate for treatment. If abscess recurs, drainage can be performed with a small incision. Excision of the lymph node can be performed in a few patients with caseification $(12,14)$. In our series, the lymph nodes of patients in their necks were reduced after 10day streptomycin therapy. At the end, the treatments of patients who did not have satisfactory healing in their lymph nodes were 
continued with doxycycline treatment until complete recovery was obtained. No patient was given treatment for longer than 3 weeks. The reason for the long duration of hospitalization was that most of our patients (88\%) applied from other cities, and the treatment procedure was planned after obtaining the test results for tularemia from the Directorate of Health rather than the continuation of disease symptoms.

\section{Conclusion}

In conclusion, tularemia should be considered for the differential diagnosis, particularly in patients from rural areas who present with the symptoms of neck swelling, sore throat, fever, and fatigue and those whose abscess material does not show bacterial growth.

Ethics Committee Approval: Ethics committee approval was received for this study from Firat University Clinical Research Ethics Committee.

Informed Consent: Written informed consent was obtained from patients who participated in this study.

Peer-review: Externally peer-reviewed.

Author Contributions: Concept - T.K., E.K., İ.K., K.Y., Ş.Y.; Design - T.K., K.Y.; Supervision - T.K.; Data Collection and/or Processing T.K., E.K., I.K., K.Y., Ş.Y.; Analysis and/or Interpretation - T.K., K.Y.; Literature Review - T.K., K.Y.; Writing - T.K., K.Y.; Critical Review - T.K., E.K., İK., K.Y., Ş.Y.

Conflict of Interest: No conflict of interest was declared by the authors.

Financial Disclosure: The authors declared that this study has received no financial support.

\section{References}

1. Richard FJ, Gordon ES. Tularemia. In: Dennis LK, Anthony SF, editors. Harrison's Infectious Diseases. New York: The McGraw-Hill; 2010. p.552-57.
2. T.C. Sağlık Bakanlığı Temel Sağlık Hizmetleri Genel Müdürlüğü Zoonotik Hastalıklar Daire Başkanlığı. Tularemi hastalığının kontrolü için saha rehberi. Ankara, 2011.

3. Janet EF, Nathan CN. Tularemia. Vet Microbiol 2010; 140: 33238. [CrossRef]

4. Turhan V, Berber U, Haholu A, Salihoglu M, Ulcay A. Differential diagnosis of cervical lymphadenitis mimicking malignancy due to tularemia: our experiences. Indian J Pathol Microbiol 2013; 56: 252-57. [CrossRef]

5. Ohara Y, Sato T, Fujita H, Ueno T, Homma M. Clinical manifestations of tularemia in Japan - Analysis of 1355 cases observed between 1924 and 1987. Infection 1991; 19: 14-7. [CrossRef]

6. Brad G, Alex D, David RK, Kevin AC. Ulceroglandular tularemia in a nonendemic area. South Med J 2007; 100: 304-8. [CrossRef]

7. Helvacı S, Gedikoğlu S, Akalın H, Oral HB. Tularemia in Bursa, Turkey: 205 cases in ten years. Eur J Epidemiol 2000; 16: 271-6. [CrossRef]

8. Ben B, David TD. Tularemia. In: Jonathan C, Steven MO, William GP, editors. Infectious Diseases. China: Elsevier; 2010. p.1226-30.

9. Cağlı S, Vural A, Sönmez O, Yüce I, Güney E. Tularemia: A rare cause of neck mass, evaluation of 33 patients. Eur Arch Otorhinolaryngol 2011; 268: 1699-704. [CrossRef]

10. Kaya A, Deveci K, Uysal İÖ, Güven AS, Demir M, Uysal EB et al. Tularemia in children: evaluation of clinical, laboratory and therapeutic features of 27 tularemia cases. Turk J Pediatr 2012; 54: 10512.

11. Engin A, Altuntaş EE, Cankorkmaz L, Kaya A, Elaldi N, Şimşek $\mathrm{H}$, et al. The first tularemia out break in the Sivas province: A review of 29 cases. Klimik Dergisi 2011; 24: 17-23. [CrossRef]

12. Erdem H, Ozturk-Engin D, Yesilyurt M, Karabay O, Elaldi N, Celebi G, et al. Evaluation of tularaemia courses: a multicentre study from Turkey. Clin Microbiol Infect 2014; 20: O1042-51. [CrossRef]

13. Dogan-Gun B, Bahadır B, Celebi G, Numanoglu G, Ozdamar SO, Mocan-Kuzey G. Fine needle aspiration cytology finding in cases diagnosed as oropharyngeal tularemia lymphadenitis. Turk J Pathol 2007; 23: 38-42.

14. Karabay O, Kilic S, Gurcan S, Pelitli T, Karadenizli A, Bozkurt $\mathrm{H}$, et al. Cervical lymphadenitis: tuberculosis or tularaemia? Clin Microbiol Infect 2013; 19: E113-7. [CrossRef] 